UDC $624.04,519.853$

\title{
OPTIMAL NUMBERS OF THE REDUNDANT MEMBERS FOR INTRODUCING INITIAL PRE-STRESSING FORCES INTO STEEL BAR STRUCTURES
}

\author{
V. V. Yurchenko ${ }^{1}$, \\ Doctor of Technical Science, Associate Professor \\ I. D. Peleshko ${ }^{2}$, \\ Candidate of Technical Science, Associate Professor \\ ${ }^{1}$ Kyiv National University of Construction and Architecture \\ Povitroflotskyj av., 31, Kyiv, 03680 \\ ${ }^{2}$ Lviv Polytechnic National University \\ St. Bandery, 12, Lviv, 79013
}

DOI: $10.32347 / 2410-2547.2021 .106 .68-91$

\begin{abstract}
The paper considers parametric optimization problems for the steel bar structures formulated as nonlinear programming ones with variable unknown cross-sectional sizes of the structural members, as well as initial prestressing forces introduced into the specified redundant members of the structure. The system of constraints covers load-bearing capacity constraints for all the design sections of the structural members subjected to all the design load combinations at ultimate limit state, as well as displacement constraints for the specified nodes of the bar system, subjected to all design load combinations at serviceability limit state. The method of the objective function gradient projection onto the active constraints surface with simultaneous correction of the constraints violations has been used to solve the parametric optimization problem. A numerical technique to determine the optimal number of the redundant members to introduce the initial prestressing forces has been offered for high-order statically indeterminate bar structures. It reduces the dimension for the design variable vector of unknown initial prestressing forces for considered optimization problems.
\end{abstract}

Keywords: parametric optimization, redundant member, initial prestressing force, optimal prestressing, sensitivity analysis, gradient projection method.

Introduction. The concept of pre-stressing steel structures is only recently being re-considered, despite a long and successful history of pre-stressing concrete members. In spite of having many advantages over pre-stressed concrete, pre-stressed steel has not been popular due to the complexity and ambiguity involved in analysis and design calculations and problems arising due to application of external pre-stressing technique and fabrication [1].

Early work on the pre-stressing of steel structures was described by Magnel [2] in 1950, where it was shown experimentally that improved economy can be achieved by pre-stressing truss girders. More recent studies have explored the behavior and design of pre-stressed steel beams [3], flooring systems [4], columns $[5,6]$, trusses $[7,8]$ and space trusses [9]. Studies of the structural response of sub-assemblies and the overall response of pre-stressed frames with sliding joints have been also carried out [10], as has a numerical investigation into the stress-erection process of such systems [11]. Each of the 
above described studies identified potential economies and enhanced performance through the use of pre-stressing [1].

A number of research works were dedicated to the optimization of prestressed bar structures. Usually applied optimum design problems for the prestressed bar structures are formulated as parametric optimization problems, namely as searching problems for unknown structural parameters, whose provide an extreme value of the specified purpose function in the feasible region defined by the specified constraints [12]. For this purpose, research papers [13, 14, 15, 16] use mathematical programming methods where optimal design is divided into several stages, where a search is completed at each stage after varying values of a specific group of parameters. Introduction of such stage-by-stage procedures may in many cases distort the conditions of optimization tasks.

In the papers $[17,18]$ an algorithm for searching for the optimum values of the parameters of pre-stressed steel arch trusses with high-strength ties has been developed. The problem in focus is to reduce the cost of the operating trusses while taking into consideration the strength, stiffness and stability constraints formulated according to design code requirements. The optimization is performed via a genetic algorithm. The strain-stress state of the structure variants is calculated basing upon the finite element method. The feasibility of the suggested method was illustrated for optimal engineering of a steel truss with a $60 \mathrm{~m}$ span, pre-stressed with a double-lay rope.

Pre-stress of the statically indeterminate bar system can be created by introducing the initial pre-stressing forces into the redundant members of the structural system. The number of initial pre-stressing forces introduced into the bar system can be less or equal to the degree of static indeterminacy of the bar system or the number of the redundant members.

Optimum distribution of the internal forces and material in the bar structure corresponded to the least structural weight can be achieved by introducing initial pre-stressing forces into the all redundant members of the bar system. But economical efficiency caused by regulation of the internal forces should be estimated taking into account additional costs required to create pre-stressing in the structural system. The fewer the redundant members in the pre-stressing process of the structure will be subject to initial deformations, the lower the costs associated with creating pre-stressing in the bar system.

Complex high-order statically indeterminate bar systems with great amount of the redundant members have lots of pre-stressing variants for them. For such structures proposed numerical techniques to determine optimal pre-stressing variant require a great amount of the calculations related to solving the optimization problems for each pre-stressing variant or due to the high dimension of the design variable vector for unknown initial pre-stressing forces.

In this paper, pre-stressed high-order statically indeterminate bar structure is considered as research object. This object is being investigated to find the optimal distribution of internal forces and material in the bar system.

Although many papers are published on the parametric optimization of the pre-stressed bar structures, the development of a numerical technique to determine the optimal number of the redundant members to introduce initial pre- 
stressing forces for high-order statically indeterminate bar structures remains an actual task. Therefore, the main research goal is the development of numerical algorithm to solve parametric optimization problems of the pre-stressed bar structures with searching for the optimal number of the redundant members to introduce initial pre-stressing forces. The following research tasks are states accordingly: to propose a numerical technique to determine the optimal number of the redundant members to introduce initial pre-stressing forces for high-order statically indeterminate bar structures; to show by numerical examples that proposed numerical technique ensures decreasing of the number of optimum material and internal forces distribution problems that should be solved, as well as reduction of the dimension for the design variable vector of unknown initial pre-stressing forces for considered optimization problems.

1. Problem formulation for parametric optimization of steel structures. Let us consider a parametric optimization problem of a structure consisting of bar members. The problem statement can be performed taking into account the following assumptions widely used in structural mechanic problems: the material of the structure is ideal elastic; the bar structure is deformable linearly; external loadings applied to the structure are quasi-static.

Let us also formulate the following pre-conditions for calculation: crosssection types and dimensions of structural members are constant along member lengths; external loadings are applied to the structural members without eccentricities relating to the center of mass and shear center of its cross-sections; an additional restraining by stiffeners are provided in the design sections where point loads (reactions) applied with the exception of crosssection warping and local buckling of the cross-section elements; load-carrying capacity of the structural joints, splices and connections are provided by additional structural parameters do not covered by the considered parametric optimization problem.

A parametric optimization problem of the structure can be formulated as presented below: to find optimum values for geometrical parameters of the structure, member's cross-section dimensions and initial pre-stressing forces introduced into the specified redundant members of the bar system, which provide the extreme value of the determined optimality criterion and satisfy all load-carrying capacities and stiffness requirements. We assume, that the structural topology, cross-section types and node type connections of the bars, the support conditions of the bar system, as well as loading and pre-stressing patterns are prescribed and constants.

The formulated parametric optimization problem can be considered integrally using the mathematical model in the form of the non-linear programming task including an objective function, a set of independent design variables and constraints, which reflect generally non-linear dependences between them. The validity of the mathematical model can be estimated by the compliance of its structure with the design code requirements.

The parametric optimization problem of steel structures can be stated in the following mathematical terms: to find unknown structural parameters 
$\vec{X}=\left\{X_{\imath}\right\}^{T}, \imath=\overline{1, N_{X}}$, providing the least value of the determined objective function:

$$
f^{*}=f\left(\vec{X}^{*}\right)=\min _{\vec{X} \in \mathfrak{I}_{\square}} f(\vec{X}),
$$

in a feasible region (search space) $\mathfrak{I}$ defined by the following system of constraints:

$$
\begin{gathered}
\boldsymbol{\psi}(\vec{X})=\left\{\psi_{\kappa}(\vec{X})=0 \mid \kappa=\overline{1, N_{E C}}\right\}, \\
\varphi(\vec{X})=\left\{\varphi_{\eta}(\vec{X}) \leq 0 \mid \eta=\overline{N_{E C}+1, N_{I C}}\right\},
\end{gathered}
$$

where $\vec{X}$ is the vector of the design variables (unknown structural parameters); $f, \psi_{\kappa}, \varphi_{\eta}$ are the continuous functions of the the vector argument; $\vec{X}^{*}$ is the optimum solution or optimum point (the vector of optimum values of the structural parameters); $f^{*}$ is the optimum value of the optimum criterion (objective function); $N_{E C}$ is the number of constraintsequalities $\psi_{K}(\vec{X})$, whose define hyperplanes of the feasible solutions; $N_{I C}$ is the number of constraints-inequalities $\varphi_{\eta}(\vec{X})$, whose define a feasible region in the design space $\mathfrak{I}$.

The vector of the design variables comprises of unknown geometrical parameters of the structure $\vec{X}_{G}=\left\{X_{G, \chi}\right\}^{T}, \quad \chi=\overline{1, N_{X, G}}$, unknown crosssectional dimensions of the structural members $\vec{X}_{C S}=\left\{X_{C S, \alpha}\right\}^{T}, \alpha=\overline{1, N_{X, C S}}$, as well as unknown initial pre-stressing forces $\vec{X}_{P S}=\left\{X_{P S, \beta}\right\}^{T}, \beta=\overline{1, N_{X, P S}}$, introduced into the specified redundant members of the structure (see Fig. 1.1):

$$
\vec{X}=\left\{\vec{X}_{G}, \vec{X}_{C S}, \vec{X}_{P S}\right\}^{T}=\left\{\left\{X_{G, \chi}\right\},\left\{X_{C S, \alpha}\right\},\left\{X_{P S, \beta}\right\}\right\}^{T},
$$

where $N_{X, G}$ is the total number of unknown node coordinates of the steel structure; $N_{X, C S}$ is the total number of unknown cross-sectional dimensions of the structural members, $N_{X, P S}$ is the total number of unknown initial prestressing forces introduced into the specified redundant members of the bar system, $N_{X, G}+N_{X, C S}+N_{X, P S}=N_{X}$.

In cases when vector of the design variables $\vec{X}$ consists of unknown crosssectional dimensions only:

$$
\vec{X}=\vec{X}_{C S}=\left\{X_{C S, \alpha}\right\}^{T},
$$

then optimum material distribution problem (1.1)-(1.3), (1.5) for the steel structure is under consideration. The vector of the design variables $\vec{X}$ can also consists of unknown initial pre-stressing forces $\vec{X}_{P S}=\left\{X_{P S, \beta}\right\}^{T}, \beta=\overline{1, N_{X, P S}}$, introduced into the specified redundant members of the structure: 


$$
\vec{X}=\left\{\vec{X}_{C S}, \vec{X}_{P S}\right\}^{T}=\left\{\left\{X_{C S, \alpha}\right\},\left\{X_{P S, \beta}\right\}\right\}^{T},
$$

where $N_{X, C S}+N_{X, P S}=N_{X}$. In cases when vector of the design variables $\vec{X}$ consists of unknown cross-sectional dimensions and unknown initial prestressing forces, then optimum material and internal forces distribution problem $(1.1)-(1.3),(1.6)$ for the steel structure is under consideration.

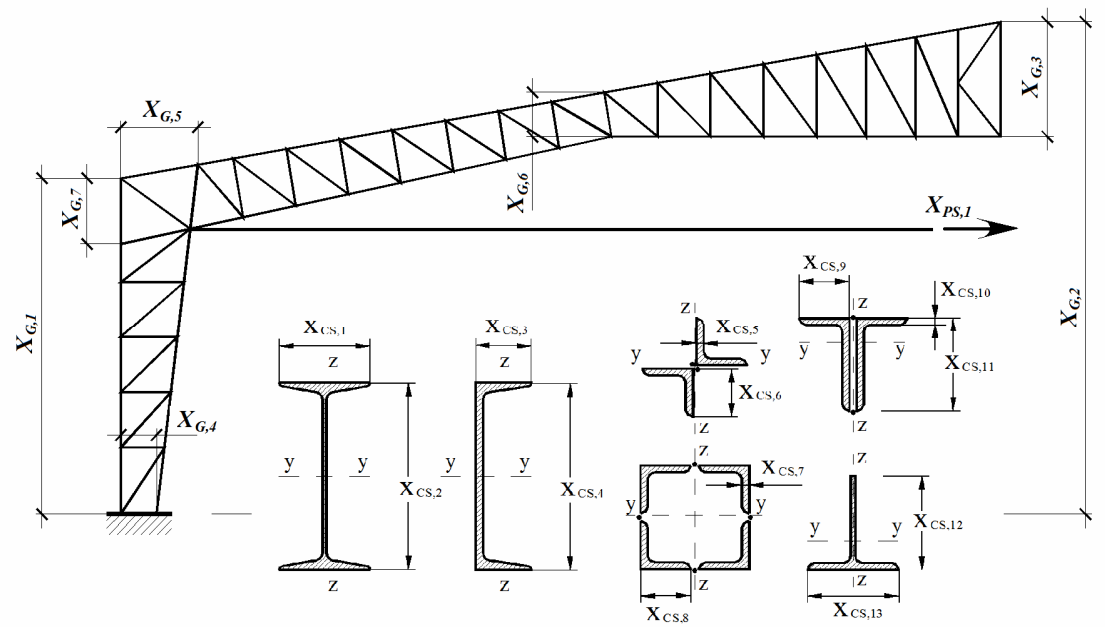

Fig. 1.1. The unknown (variable) parameters of the structure considered as design variables

The specific technical-and-economic index (material weight, material cost, construction cost etc.) or another determined indicator can be considered as the objective function (1.1) taking into account the ability to formulate its analytical expression as a function of design variables $\vec{X}$.

Load-carrying capacities constraints (strength and stability inequalities) for all design sections of the structural members subjected to all design load combinations at the ultimate limit state as well as displacements constraints (stiffness inequalities) for the specified nodes of the bar system subjected to all design load combinations at the serviceability limit state should be included into the system of constraints (1.2)-(1.3). Additional requirements whose describe structural, technological and serviceability particularities of the considered structure can be included into the system (1.2) - (1.3) as well.

The design internal forces in the structural members used in the strength and stability inequalities of the system (1.2) - (1.3) are considered as state variables depending on design variables $\vec{X}$ and can be calculated from the following linear equations system of the finite element method [19]:

$$
\mathbf{K}\left(\vec{X}_{G}, \vec{X}_{C S}\right) \times \vec{z}_{U L S, k}=\vec{p}_{U L S, k}\left(\vec{X}_{G}, \vec{X}_{P S}\right), k=\overline{1, N_{L C}^{U L S}},
$$

where $\mathbf{K}\left(\vec{X}_{G}, \vec{X}_{C S}\right)$ is the stiffness matrix of the finite element model of the 
bar system, which should be formed depending on the unknown (variable) cross-sectional dimensions of the structural members $\vec{X}_{C S}$, as well as unknown (variable) node coordinates of the structure $\vec{X}_{G} ; \vec{p}_{U L S, k}\left(\vec{X}_{G}, \vec{X}_{P S}\right)$ is the column-vector of the node's loads for $k^{\text {th }}$ design load combination of the ultimate limit state, which should be formed depending on unknown (variable) initial pre-stressing forces $\vec{X}_{P S}$, as well as unknown (variable) node coordinates of the structure $\vec{X}_{G} ; \vec{z}_{U L S, k}$ is the result column-vector of the node displacements for $k^{\text {th }}$ design load combination of the ultimate limit state, $\vec{z}_{U L S, k}=\mathbf{Z}_{\mathbf{F E M}, k}^{U L S}\left(\vec{X}_{G}, \vec{X}_{C S}, \vec{X}_{P S}\right)=\mathbf{Z}_{\mathbf{F E M}, k}^{U L S}(\vec{X}) ; N_{L C}^{U L S}$ is the number of the design ultimate load combinations. For each $i^{\text {th }}$ design section of $j^{\text {th }}$ structural member subjected to $k^{\text {th }}$ ultimate design load combination the design internal forces (axial force, bending moments and shear forces) can be calculated depending on node displacement column-vector $\vec{z}_{U L S, k}$.

The node displacement of the bar system used in stiffness inequalities of the system (1.2) - (1.3) are also considered as state variables depending on design variables $\vec{X}$ and can be calculated from the following linear equations system of the finite element method [19]:

$$
\mathbf{K}\left(\vec{X}_{G}, \vec{X}_{C S}\right) \times \vec{z}_{S L S, k}=\vec{p}_{S L S, k}\left(\vec{X}_{G}, \vec{X}_{P S}\right), k=\overline{1, N_{L C}^{S L S}},
$$

where $\vec{p}_{S L S, k}\left(\vec{X}_{P S}\right)$ is the column-vector of the node's loads for $k^{\text {th }}$ design load combination of the serviceability limit state, which should be formed depending on unknown (variable) initial pre-stressing forces $\vec{X}_{P S}$, as well as unknown (variable) node coordinates of the structure $\vec{X}_{G} ; \vec{z}_{U L S, k}$ is the result column-vector of the node displacements for $k^{\text {th }}$ design load combination of the serviceability limit state, $\vec{z}_{S L S, k}=\mathbf{Z}_{\mathrm{FEM}, k}^{S L S}\left(\vec{X}_{G}, \vec{X}_{C S}, \vec{X}_{P S}\right)=\mathbf{Z}_{\mathrm{FEM}, k}^{S L S}(\vec{X}) ; N_{L C}^{S L S}$ is the number of the design serviceability load combinations. For each $m^{\text {th }}$ node of the finite element model subjected to $k^{\text {th }}$ serviceability design load combination the design vertical and horizontal displacements can be calculated depending on node displacement column-vector $\vec{z}_{S L S, k}$.

The system of constraints (1.2) - (1.3) should cover strength and stability constraints formulated for all design sections of all structural members of the considered steel structure subjected to all design load combinations at the ultimate limit state. The following strength constraints should be included in the system of constraints (1.2)-(1.3), formulated for all design sections, $\forall i=\overline{1, N}_{D S}$, of all structural members, $\forall j=\overline{1, N_{B}}$, subjected to all ultimate load case combination, $\forall k=\overline{1, N_{L C}^{U L S}}$, namely:

- normal stresses verifications: 


$$
\frac{\sigma_{\max , i j k}(\vec{X})}{R_{y} \gamma_{c}}-1 \leq 0 ;
$$

- shear stresses verifications:

$$
\frac{\tau_{\max , i j k}(\vec{X})}{0.58 R_{y} \gamma_{c}}-1 \leq 0 ;
$$

- as well as equivalent stresses verifications:

$$
\frac{\sigma_{e q v, i j k}(\vec{X})}{1.15 R_{y} \gamma_{c}}-1=\frac{\sqrt{\sigma_{x, i j k}^{2}(\vec{X})+3 \tau_{x, j i k}^{2}(\vec{X})}}{1.15 R_{y} \gamma_{c}}-1 \leq 0,
$$

where $\sigma_{\max , i j k}(\vec{X})$ are $\tau_{\max , i j k}(\vec{X})$ are the maximum value of the normal and shear stresses respectively caused by internal forces (axial force, bending moments and shear forces) acting in $i^{\text {th }}$ design section of $j^{\text {th }}$ structural member subjected to $k^{\text {th }}$ ultimate load case combination calculated from the linear equations system of the finite element method (1.7); $\gamma_{c}$ is the safety factor [20]; $R_{y}$ is the design strength for steel member subjected to tension, bending and compression; $R_{y} \gamma_{c}, 0.58 R_{y} \gamma_{c}$ and $1.15 R_{y} \gamma_{c}$ are allowable values for normal, shear and equivalent stresses respectively [20]; $N_{D S}$ is the number of design sections in structural members; $N_{B}$ is the number of structural members; $\sigma_{x, i j k}(\vec{X}), \tau_{x, i j k}(\vec{X})$ and $\sigma_{e q v, i j k}(\vec{X})$ are normal, shear and equivalent stresses respectively at the specified cross-section point caused by internal forces acting in $i^{\text {th }}$ design section of $j^{\text {th }}$ structural member subjected to $k^{\text {th }}$ ultimate load case combination calculated from the linear equations system of the finite element method (1.7). The maximum value of the normal $\sigma_{\text {max }, i j k}(\vec{X})$ and shear stresses $\tau_{\text {max }, i j k}(\vec{X})$, as well as normal $\sigma_{x, j j k}(\vec{X})$, shear $\tau_{x, i j k}(\vec{X})$ and equivalent $\sigma_{e q v, i j k}(\vec{X})$ stresses at the specified cross-section point should be calculated depending on the variable geometrical parameters of the structure $\vec{X}_{G}$, variable initial pre-stressing forces $\vec{X}_{P S}$ and variable cross-sectional dimensions of the structural members $\vec{X}_{C S}$.

The following stability constraints should be included in the system of constraints (1.2)-(1.3), formulated for all design sections, $\forall i=\overline{1, N}_{D S}$, subjected to all ultimate load case combination, $\forall k=\overline{1, N_{L C}^{U L S}}$, namely:

- flexural buckling verifications for all column structural members, $\forall j=\overline{1, N_{C M}}$ :

$$
\frac{\sigma_{\text {max }, i j k}(\vec{X})}{\varphi_{y, j}\left(\vec{X}_{G}, \vec{X}_{C S}\right) R_{y} \gamma_{c}}-1 \leq 0,
$$




$$
\frac{\sigma_{\max , i j k}(\vec{X})}{\varphi_{z, j}\left(\vec{X}_{G}, \vec{X}_{C S}\right) R_{y} \gamma_{c}}-1 \leq 0 ;
$$

- torsional-flexural buckling verifications for all column structural members, $\forall j=\overline{1, N_{C M}}$ :

$$
\frac{\sigma_{\max , i j k}(\vec{X})}{\varphi_{c, j}\left(\vec{X}_{G}, \vec{X}_{C S}\right) R_{y} \gamma_{c}}-1 \leq 0 ;
$$

- lateral-torsional buckling verifications for all beam structural members, $\forall j=\overline{1, N_{B M}}$ :

$$
\frac{\sigma_{\max , i j k}(\vec{X})}{\varphi_{b, j}\left(\vec{X}_{G}, \vec{X}_{C S}\right) R_{y} \gamma_{c}}-1 \leq 0,
$$

where $\varphi_{y, j}\left(\vec{X}_{G}, \vec{X}_{C S}\right)$ and $\varphi_{z, j}\left(\vec{X}_{G}, \vec{X}_{C S}\right)$ are column's stability factors corresponded to flexural buckling relative to main axes of inertia and calculated depending on the design lengths $l_{e f, y, j}, l_{e f, z, j}$, cross-section type and crosssection geometrical properties for the $j^{\text {th }}$ structural member [20]; $\varphi_{c, j}\left(\vec{X}_{G}, \vec{X}_{C S}\right)$ is the column's stability factor corresponded to torsional-flexural buckling and calculated depending on the design lengths $l_{e f, y, j}, l_{e f, z, j}, l_{e f, T, j}$, cross-section type and cross-section geometrical properties for the $j^{\text {th }}$ structural member [20]; $N_{C M}$ is the number of column structural members; $\varphi_{b, j}\left(\vec{X}_{G}, \vec{X}_{C S}\right)$ is the beam's stability factor corresponded to lateral-torsional buckling and calculated depending on the design length $l_{e f, b, j}$, cross-section type and cross-section geometrical properties for the $j^{\text {th }}$ structural member [20]; $N_{B M}$ is the number of beam structural members. The flexural buckling factors $\varphi_{y, j}\left(\vec{X}_{G}, \vec{X}_{C S}\right)$ and $\varphi_{z, j}\left(\vec{X}_{G}, \vec{X}_{C S}\right)$, as well as torsional-flexural buckling factor $\varphi_{c, j}\left(\vec{X}_{G}, \vec{X}_{C S}\right)$ and the lateral-torsional buckling factor $\varphi_{b, j}\left(\vec{X}_{G}, \vec{X}_{C S}\right)$ should be calculated depending on the variable geometrical parameters of the structure $\vec{X}_{G}$ and variable cross-sectional dimensions of the structural members $\vec{X}_{C S}$.

The following buckling verifications for beam-column structural members should also be included in the system of constraints (1.2) - (1.3), formulated for all design sections, $\forall i=\overline{1, N}_{D S}$, of all beam-column structural members, $\forall j=\overline{1, N_{B C M}}$, subjected to all ultimate load case combination, $\forall k=\overline{1, N_{L C}^{U L S}}$, namely:

$$
\frac{\sigma_{\max , j k k}(\vec{X})}{\varphi_{e, j i k}(\vec{X}) R_{y} \gamma_{c}}-1 \leq 0
$$




$$
\frac{\sigma_{\text {max }, i j k}(\vec{X})}{\varphi_{y, j}\left(\vec{X}_{G}, \vec{X}_{C S}\right) c_{i j k}(\vec{X}) R_{y} \gamma_{c}}-1 \leq 0,
$$

where $\varphi_{e, i j k}(\vec{X})$ and $c_{i j k}(\vec{X})$ are beam-column's stability factors corresponded to in-plane and out-of-plane buckling and calculated depending on the internal forces (ration of the bending moment to the axial force), as well as depending on the design lengths $l_{e f, y, j}, l_{e f, z, j}$, cross-section type and cross-section geometrical properties for the $j^{\text {th }}$ structural member [20]; $N_{B C M}$ is the total number of beam-column structural members, $N_{B C M}+N_{C M}+N_{B M}=N_{B}$. The beam-column's stability factors $\varphi_{e, i j k}(\vec{X})$ and $c_{i j k}(\vec{X})$ should be calculated depending on variable geometrical parameters of the structure $\vec{X}_{G}$, variable cross-sectional dimensions of the structural members $\vec{X}_{C S}$ and variable initial pre-stressing forces $\vec{X}_{P S}$.

The following local buckling constraints should also be included into the system of constraints:

$$
\begin{aligned}
& \frac{\bar{\lambda}_{w, j}\left(\vec{X}_{C S}\right)}{\bar{\lambda}_{u w, j}(\vec{X})}-1 \leq 0, \\
& \frac{\bar{\lambda}_{f, j}\left(\vec{X}_{C S}\right)}{\bar{\lambda}_{u f, j}(\vec{X})}-1 \leq 0,
\end{aligned}
$$

where $\bar{\lambda}_{w, j}\left(\vec{X}_{C S}\right)$ and $\bar{\lambda}_{f, j}\left(\vec{X}_{C S}\right)$ are the non-dimensional slenderness of the web and flange respectively of the cross-section for $j^{\text {th }}$ structural member; $\bar{\lambda}_{u w, j}(\vec{X})$ and $\bar{\lambda}_{u f, j}(\vec{X})$ are the maximum values for corresponded nondimensional slenderness for column, beam and beam-column structural members calculated depending on the internal forces (ration of the bending moment to the axial force), as well as depending on the design lengths $l_{e f, y, j}$, $l_{e f, z, j}$, cross-section type and cross-section geometrical properties for the $j^{\text {th }}$ structural member [20]. The non-dimensional slenderness $\bar{\lambda}_{w, j}\left(\vec{X}_{C S}\right)$ and $\bar{\lambda}_{f, j}\left(\vec{X}_{C S}\right)$ should be calculated depending on the variable cross-sectional dimensions of the structural members $\vec{X}_{C S}$ only. At the same time, the maximum values for corresponded non-dimensional slenderness $\bar{\lambda}_{u w, j}(\vec{X})$ and $\bar{\lambda}_{u f, j}(\vec{X})$ should be calculated depending on the variable geometrical parameters of the structure $\vec{X}_{G}$ and variable cross-sectional dimensions of the structural members $\vec{X}_{C S}$ and variable initial pre-stressing forces $\vec{X}_{P S}$.

The system of constraints (1.2) - (1.3) should also cover the displacements 
constraints (stiffness inequalities) for the specified nodes of the considered steel structure subjected to all design load combinations at the serviceability limit state. The following horizontal and vertical displacements constraints should be included into the system of constraints (1.2) - (1.3), formulated for all nodes, $\forall m=\overline{1, N_{N}}$, of the steel structure subjected to all serviceability load case combination, $\forall k=\overline{1, N_{L C}^{S L S}}$, namely:

$$
\begin{aligned}
& \frac{\delta_{x, m k}(\vec{X})}{\delta_{u x, m}}-1 \leq 0, \\
& \frac{\delta_{z, m k}(\vec{X})}{\delta_{u z, m}}-1 \leq 0,
\end{aligned}
$$

where $\delta_{x, m k}(\vec{X})$ and $\delta_{z, l k}(\vec{X})$ are the horizontal and vertical displacements respectively for $l^{\text {th }}$ node of the steel structure subjected to $k^{\text {th }}$ serviceability load case combination calculated from the linear equations system of the finite element method (1.8); $\delta_{u x, l}$ and $\delta_{u z, l}$ are the allowable horizontal and vertical displacements for $l^{\text {th }}$ structural node; $N_{N}$ is the number of nodes in the considered steel structure.

Additional requirements, whose describe structural, technological and serviceability particularities of the considered structure, as well as constraints on the building functional volume can be also included into the system (1.2) (1.3). In particular these requirements can be presented in the form of constraints on lower and upper values of the design variables, $\forall \boldsymbol{\imath}=\overline{1, N_{X}}$ :

$$
\begin{aligned}
& 1-\frac{X_{l}}{X_{l}^{L}} \leq 0, \\
& \frac{X_{l}}{X_{l}^{U}}-1 \leq 0,
\end{aligned}
$$

where $X_{\imath}^{L}$ and $X_{l}^{U}$ are the lower and upper bounds for the design variable $X_{\imath}$.

The parametric optimization problem stated as non-linear programming task by (1.1) - (1.3) can be successfully solved using a gradient projection non-linear methods [21] in cases if the purpose function and constraints of the mathematical model are continuously differentiable functions, as well as the search space is smooth $[22,23]$. The method of objective function gradient projection onto the active constraints surface with simultaneous correction of the constraints violations ensures effective searching for solution of the nonlinear programming tasks occurred when optimum designing of the building structures [24, 25]. Additionally, a sensitivity analysis is a useful optional feature [26] that could be used in the scope of numerical algorithms which are developed based on the gradient methods.

2. A numerical algorithm to determine optimal pre-stressing variant of bar structures. A certain $\beta^{\text {th }}$ pre-stressing variant $\mathbf{V}_{\beta}$ of the bar structure can 
be definitely described by the set of redundant members $\mathbf{r}_{\beta}=\left\{r_{\beta, \mu}\right\}, \mu=\overline{1, N}_{R M, \beta}$, and by the value of the initial pre-stressing force $X_{P S, \beta}$ introduced into these members, $\mathbf{V}_{\beta}=\left\{\mathbf{r}_{\beta}, X_{P S, \beta}\right\}=\left\{\left\{r_{\beta, \mu}\right\}, X_{P S, \beta}\right\}$, $\mu=\overline{1, N}_{R M, \beta}$ here $N_{R M, \beta}$ is the number of redundant members for $\beta^{\text {th }}$ prestressing variant $\mathbf{V}_{\beta}$.

The set of the pre-stressing variants is $\mathbf{B}=\left\{\mathbf{V}_{\beta}\right\}=\left\{\mathbf{r}_{\beta}, X_{P S, \beta}\right\}, \beta=\overline{1, N_{X, P S}}$. In general case, the number of such variants equals to the redundancy of the bar system. The number of initial prestressing forces introduced into the bar system can be less or equal to the degree of static indeterminacy of the bar system or the number of the redundant members $N_{D S I}$, namely $\sum_{\beta=1}^{N_{X, P S}} N_{R M, \beta} \leq N_{D S I}$.

The dimension $\beta$ of set $\mathbf{B}$ can be significantly reduced taking into account the symmetry of the considered structural form. The design variables vector $\vec{X}_{P S}=\left\{X_{P S, \beta}\right\}, \beta=\overline{1, N_{X, P S}}$ of the unknown (variable) initial prestressing forces for the considered bar system is formed according to set $\mathbf{B}=\left\{\mathbf{V}_{\beta}\right\}, \beta=\overline{1, N_{X, P S}}$, of the pre-stressing variants.

An optimal pre-stressing variant for the considered structure can be defined as a combination of some pre-stressing variants $\mathbf{V}_{\beta} \subseteq \mathbf{B}$ and presented as subset $\boldsymbol{\Theta}=\left\{\mathbf{V}_{\delta} \mid \mathbf{V}_{\delta} \in \mathbf{B}\right\}, \delta=\overline{1, \tilde{N}_{X, P S}}, \tilde{N}_{X, P S} \leq N_{X, P S}, \boldsymbol{\Theta} \subseteq \mathbf{B}$, accordingly.

In the beginning set $\boldsymbol{\Theta}$ represented the optimal pre-stressing variants is $\boldsymbol{\Theta}=\varnothing$, vector of the initial pre-stressing forces is $\vec{X}_{P S}=\varnothing$. At each iteration of the proposed algorithm one of the pre-stressing variant $\mathbf{V}_{\beta} \in \mathbf{B}$ is included into the set $\boldsymbol{\Theta}$, and the optimum material and internal forces distribution problem (1.1)-(1.3), (1.5) in the bar system should be solved.

Let us introduce in further consideration the following function (2.1) that estimates both understressing and overstressing in term of longitudinal stresses for all structural members of the bar system [27]:

$$
\mathbf{S}_{\sigma}=\sum_{k=1}^{N_{L C}} \sum_{j=1}^{N_{B}} \sum_{i=1}^{N_{D S}}\left([\sigma]-\sigma_{x, i j k}(\vec{X})\right)^{2}
$$

where $\sigma_{x, i j k}$ is the design value of the local longitudinal stress due to the bending moments and the axial force calculated in $i^{\text {th }}$ design section for $j^{\text {th }}$ structural member subjected to $k^{\text {th }}$ load case combination; $N_{D S}$ is the number of the design sections in structural members; $N_{B}$ is the number of the structural members; $[\sigma]_{x, j}$ is the maximum allowed longitudinal stresses. 
An order of the consecutive including of the pre-stressing variants $\mathbf{V}_{\beta}=\left\{\mathbf{r}_{\beta}, X_{P S, \beta}\right\}=\left\{\left\{r_{\beta, \mu}\right\}, X_{P S, \beta}\right\}, \mu=\overline{1, N}_{R M, \beta}$, from set $\mathbf{B}$ into set $\boldsymbol{\Theta}$ can be defined by the values of the components of the gradient vector for function $\mathbf{S}_{\sigma}$ (2.1) with respect to the variable pre-stressing parameters $\vec{X}_{P S}$. Pre-stressing variant $\mathbf{V}_{m}=\left\{\mathbf{r}_{m}, X_{P S, m}\right\}=\left\{\left\{r_{m, \mu}\right\}, X_{P S, m}\right\} \in \mathbf{B}, \mu=\overline{1, N}_{R M, m}$, with maximum value of the gradient of the function $\mathbf{S}_{\sigma}$ (2.1) related to the number of redundant members $N_{R M, m}$ should be included into set $\Theta$ first of all. Consecutive including of the pre-stressing variants from set $\mathbf{B}$ of the pre-defined prestressing variants into set $\boldsymbol{\Theta}$ represented the optimal pre-stressing variants should be performed until the regulation of the internal forces in the structure under consideration leads to desired decrement of the objective function.

Let us presented the following algorithm to find optimal number of the redundant members for introducing initial pre-stressing forces into the redundant members of the bar structures.

Step 0. $n=0$ is the number of optimisation problems solved. The optimal number of the redundant members to introduce the initial pre-stressing forces for considered bar system is $N_{R M}=0$. The degree of static indeterminacy of the bar system is $N_{D S I}$.

Step 1. A searching problem for optimum cross-section sizes of the considered structure without initial pre-stressing forces in the redundant members is formulated and solved in the continuum space of the unknown cross-sectional sizes $\vec{X}_{C S}$ only, namely optimum material distribution problem (1.1) - (1.3), (1.5) for the bar system is formulated and solved. As a result those optimum cross-section sizes $\vec{X}_{C S, n}^{*}$ of the structural members, whose provide the least value $f_{n}^{*}$ of the objective function (1.1) and satisfy the system of constraints (1.2)-(1.3) are defined. The number of optimization problems solved should be incremented, $n \leftarrow n+1$.

Step 2. The set of the pre-stressing variants $\mathbf{B}=\left\{\mathbf{V}_{\beta}\right\}=\left\{\mathbf{r}_{\beta}, X_{P S, \beta}\right\}, \beta=\overline{1, N_{X, P S}}$, of the bar system is pre-defined by the designer. The number of redundant members $N_{R M, \beta}$ for each pre-defined prestressing variant $\mathbf{V}_{\beta}=\left\{\mathbf{r}_{\beta}, X_{P S, \beta}\right\}=\left\{\left\{r_{\beta, \mu}\right\}, X_{P S, \beta}\right\}, \mu=1, N_{R M, \beta}$, should not exceed the degree of static indeterminacy of the bar system $N_{D S I}$, $N_{R M, \beta} \leq N_{D S I}$. Auxiliary vector $\vec{Y}_{P S}=\left\{X_{P S, \beta} \mid X_{P S, \beta} \in \mathbf{V}_{\beta}\right\}, \beta=\overline{1, N_{X, P S}}$, of the unknown initial pre-stressing forces is formed according to set $\mathbf{B}$. Start zero value for each component $X_{P S, \beta}$ of vector $\vec{Y}_{P S}$ should be assigned.

Step 3. Set of the optimal pre-stressing variants is $\boldsymbol{\Theta}=\varnothing$. Vector of the 
design variables corresponded to initial pre-stressing forces is $\vec{X}_{P S, n}=\varnothing$.

Step 4. Vector for the gradient of function $\mathbf{S}_{\sigma}(2.1)$ is calculated for all variable pre-stressing parameters (unknown initial pre-stressing forces) $\vec{Y}_{P S}$ :

$$
\nabla \mathbf{S}_{\sigma}=\left\{\frac{\partial \mathbf{S}_{\sigma}}{\partial X_{P S, \beta}}\right\} \forall X_{P S, \beta} \in \vec{Y}_{P S}, \beta=\overline{1, N_{X, P S}} .
$$

Step 5. Whichever pre-stressing variant $\quad \mathbf{V}_{m}=\left\{\mathbf{r}_{m}, X_{P S, m}\right\}=$ $=\left\{\left\{r_{m, \mu}\right\}, X_{P S, m}\right\} \in \mathbf{B}, \mu=\overline{1, N}_{R M, m}$, meets the following criteria:

$$
\frac{1}{N_{R M, m}} \cdot\left|\frac{\partial \mathbf{S}_{\sigma}}{\partial X_{P S, m}}\right| \rightarrow \max
$$

should be included into the further consideration, here $N_{R M, m}$ is the number of redundant members where initial pre-stressing force $X_{P S, m}$ is introduced, $N_{R M, m} \leq N_{D S I}$. If there are no pre-stressing variants with number of redundant members $N_{R M, m}$ less than the number of degree of static indeterminacy of the bar system $N_{D S I}$, then moving to step 10 should be executed.

Step 6. Unknown initial pre-stressing force $X_{P S, m}$ corresponding to prestressing variant $\mathbf{V}_{m}$ should be added to the design variable vector $\vec{X}_{P S, n}$, $\vec{X}_{P S, n} \leftarrow \vec{X}_{P S, n}+\left\{X_{P S, m}\right\}$.

Step 7. The optimum material and internal forces problem (1.1)-(1.3), (1.5) is formulated and solved in the continuum space of the unknown crosssectional sizes and unknown initial pre-stressing forces. Those optimum values for cross-sectional sizes $\vec{X}_{C S, n}^{*}$ and optimum values for initial pre-stressing forces $\vec{X}_{P S . n}^{*}$ are defined, $\vec{X}_{n}^{*}=\left\{\vec{X}_{C S, n}^{*}, \vec{X}_{P S, n}^{*}\right\}^{T}$, whose satisfy the system of constraints (1.2) - (1.3) and provide the least (extreme) value of the objective function $f_{n}^{*}(1.1)$. The number of optimization problems solved should be incremented, $n \leftarrow n+1$.

Step 8. If $\frac{f_{n-2}^{*}-f_{n-1}^{*}}{f_{n-1}^{*}} \geq \varepsilon$, where $\varepsilon, \quad \varepsilon=1.05 \ldots 1.10$, is the desired decrement of the objective function value caused by introducing initial prestressing force $X_{P S, m}$ in the redundant members $\mathbf{r}_{m}$ of the $m^{\text {th }}$ pre-stressing variant $\mathbf{V}_{m}=\left\{\mathbf{r}_{m}, X_{P S, m}\right\}=\left\{\left\{r_{m, \mu}\right\}, X_{P S, m}\right\}, \mu=\overline{1, N}_{R M, m}$, then $\boldsymbol{\Theta} \leftarrow \boldsymbol{\Theta}+\mathbf{V}_{m}$, $\vec{Y}_{P S} \leftarrow \vec{Y}_{P S}-\left\{X_{P S, m}\right\}$.

Optimal number of the redundant members to introduce the initial pre- 
stressing forces into the considered bar system is increased as $N_{R M} \leftarrow N_{R M}+N_{R M, m}$. The degree of static indeterminacy of the bar system is $N_{D S I} \leftarrow N_{D S I}-N_{R M, m}$. Moving to step 4 should be performed. In opposite case, when $\frac{f_{n-2}^{*}-f_{n-1}^{*}}{f_{n-1}^{*}}<\varepsilon$, then moving to step 9 should be performed.

Step 9. Introducing the initial pre-stressing force $X_{P S, m}$ into the $\mathbf{r}_{m}$ redundant members of the bar system is not effective. Returning to the previous optimum solution should be executed, $\vec{X}_{n}^{*} \leftarrow \vec{X}_{n-1}^{*}, f_{n}^{*} \leftarrow f_{n-1}^{*}$. The number of optimization problems solved should be decremented, $n \leftarrow n-1$.

Step 10. Optimal number of the redundant members to introduce the initial pre-stressing forces into the considered bar system is $N_{R M}$. Number of optimization problems solved is $n$. Optimum material and internal forces distribution corresponds to design variables vector $\vec{X}_{n}^{*}$ and objective function value $f_{n}^{*}$.

3. Results and discussions. The efficiency of the proposed numerical algorithm is presented to define the optimal number of the redundant members for introducing initial prestressing forces into the bar system, considering parametric optimization of a cross-beam structure (see Fig. 3.1).

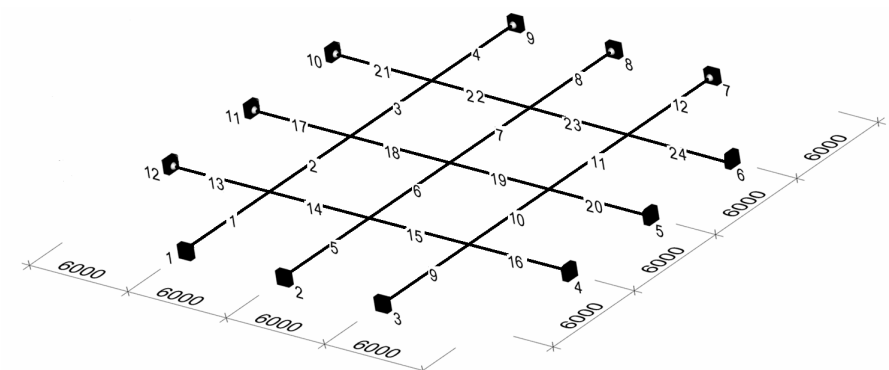

Fig. 3.1. Design scheme of the cross beam structure with node and bar numbers

The cross-beam structure is subjected to the distributed dead and live loads with characteristic value $q=25.44 \mathrm{t} / \mathrm{m}$. Applied loadings on the considered cross-beam structure are transmitted using mezzanine beams arranged with step $1 \mathrm{~m}$.

For considered cross-beam structure, steel with the following material properties is used: design resistance $R_{y}=240 \mathrm{MPa}$, modulus of elasticity $E=2.1 \times 10^{5} \mathrm{MPa}$, Poisson's ratio in elastic stage $v=0.3$ and unit weight $\gamma=7800 \mathrm{~kg} / \mathrm{m}^{3}$. For all structural members welded I-beam cross-section type is used.

Sufficient shear buckling resistance for all beam webs has been assumed ensuring by intermediate transverse and longitudinal stiffeners arranged 
according to the design code requirements [20].

Cross-section sizes for all beams have been assigned as the same, in order to have load-carrying capacity reserves in the structure, which can be further utilized by prestressing. In practice, such bearing capacity reserves may exist due to requirements of unification, restrictions on the assortment range of rolled steel profiles, etc. It should be noted that there is no need for prestressing, in cases when tapered structural members are used for considered cross-beam structure.

According to item 1 of the algorithm presented above the optimum material distribution problem (1.1) - (1.3), (1.5) has been solved for specified initial data. Cross-sectional sizes of the cross-beam structure were considered as design variables $\vec{X}_{C S}=\left(h_{w}, t_{w}, b_{f}, t_{f}\right)^{T}$, where $h_{w}$ is the beam web height, $t_{w}$ is the beam web thickness, $b_{f}$ is the beam flange width, $t_{f}$ is the beam flange thickness. The material weight $G$ was considered as the objective function (1.1):

$$
G\left(\vec{X}_{C S}\right)=\gamma\left(h_{w} t_{w}+2 b_{f} t_{f}\right) L \rightarrow \min ,
$$

where $L$ is the overall length of all beams in the structure, $L=144 \mathrm{~m}$.

Load-bearing capacities constraints (strength and stability inequalities) for all design sections of the structural members subjected to all design load combinations at the ultimate limit state have been included into the system of constraints. The following strength constraints have been considered, formulated for all design sections, $\forall i=\overline{1, N}_{D S}$, of all structural members, $\forall j=\overline{1, N}_{B}$, subjected to one ultimate load case combination, $k=1$, namely normal stresses verifications (1.9), shear stresses verifications (1.10), as well as equivalent stresses verifications (1.11). The lateral-torsional buckling constraints (1.15) have been also considered, formulated for all design sections $\forall i=\overline{1, N}_{D S}$ of all structural members $\forall j=\overline{1, N}_{B}$ according to the requirements [20], where the reduction factor for lateral-torsional buckling has been determined based on the cross sectional properties depending on the variable cross section sizes $\vec{X}_{C S}$ and takes into account the distance between lateral restraints equals to $1 \mathrm{~m}$. The local buckling constraints (1.18) - (1.19) with the maximum values for corresponded non-dimensional slenderness $\bar{\lambda}_{u w, j}=3.5$ and $\bar{\lambda}_{u f, j}=0.5$ have been also included into the system of constraints, as well as vertical displacements constraints (1.21) for specified (all internal) nodes of the cross-beam structure with the allowable vertical displacement $\delta_{u z, l}=80 \mathrm{~mm}$. 


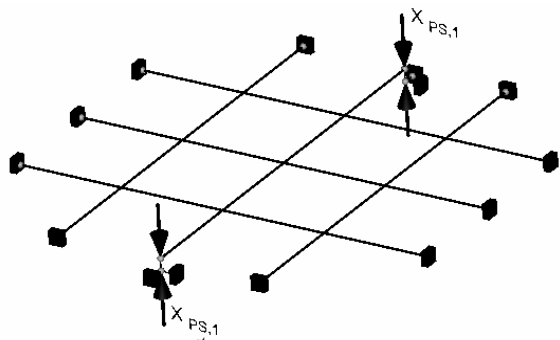

(a) $-1^{\mathrm{st}}$ pre-stressing variant

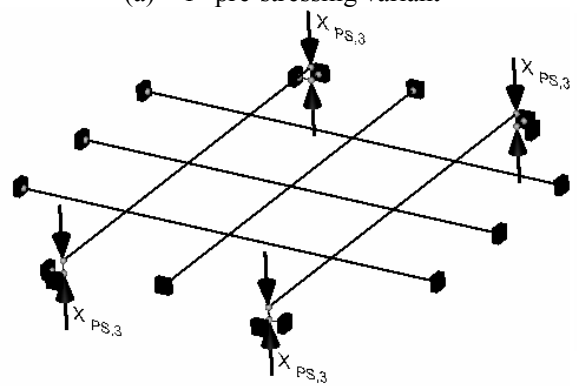

(c) $-3^{\text {rd }}$ pre-stressing variant

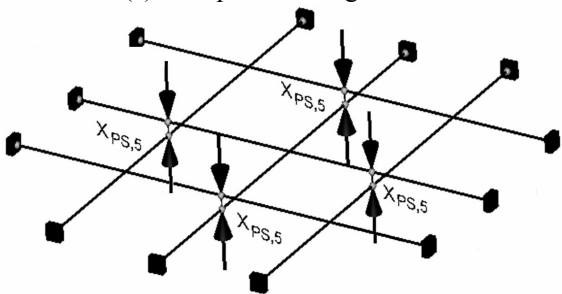

(e) $-5^{\text {th }}$ pre-stressing variant

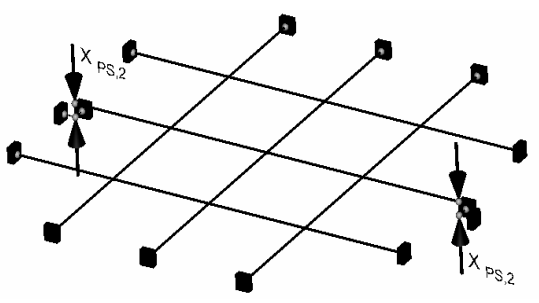

(b) $-2^{\text {nd }}$ pre-stressing variant

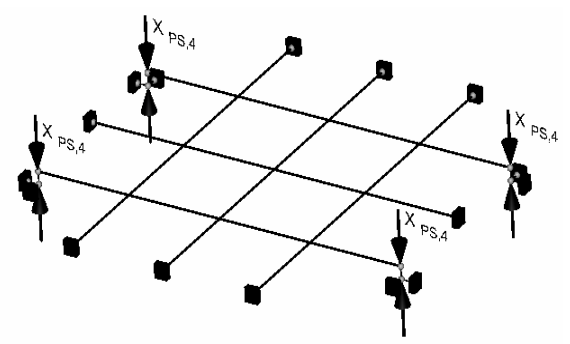

(d) $-4^{\text {th }}$ pre-stressing variant

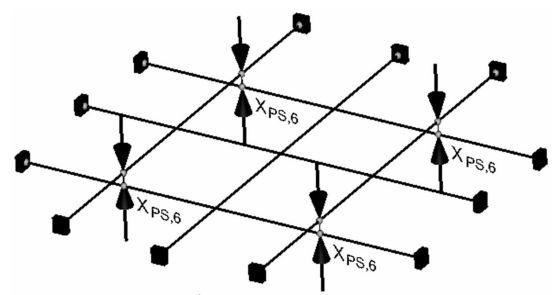

(f) $-6^{\text {th }}$ pre-stressing variant

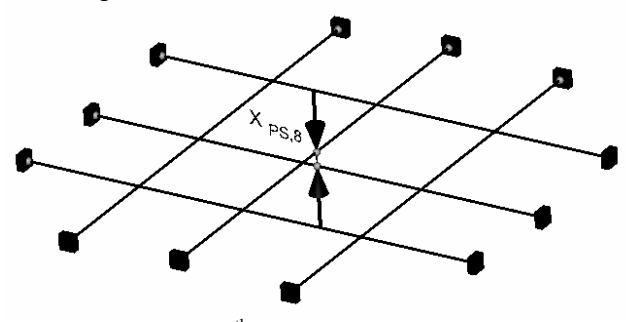

(g) $-7^{\text {th }}$ pre-stressing variant

Fig. 3.2. Pre-stressing variants for the cross beam structure by:

(a) - (d) - lowering external supports;

(e) $-(\mathrm{g})-$ vertical shifting of the beam relative to each other at their mutual intersections

The dimensions of the considered optimum material distribution problem were 4 design variables and 388 constraints. Optimum continuous crosssectional sizes $[\mathrm{cm}] \vec{X}_{C S, N_{R M}=0}^{*}=(207.2560,2.0211,79.7388,2.6526)^{T}$ for all beams of the cross-beam structure corresponded to the material weight 
$G_{N_{R M}=0}^{*}=94.5647$ ton of the structure has been obtained for the case when the number of redundant members to introduce initial pre-stressing forces equals to zero, $N_{R M}=0$. There were 98 active constraints in the optimum point including strength constraints (1.9) formulated for $6^{\text {th }}$ and $7^{\text {th }}$ structural members (see Fig. 3.1), as well as local buckling constraints (1.18), (1.19) formulated for all design sections of all structural members. The set of linearindependent constrains included 3 constraints only, namely 2 local buckling constraints (1.18), (1.19) for $1^{\text {st }}$ structural members and strength constraint (1.9) for $7^{\text {th }}$ structural member (see Fig. 3.1).

The set of the pre-stressing variants for considered cross-beam structure $\mathbf{B}=\left\{\mathbf{V}_{\beta}\right\}=\left\{\mathbf{r}_{\beta}, X_{P S, \beta}\right\}, \beta=\overline{1, N_{X, P S}}, \quad N_{X, P S}=7$, has been pre-defined (see Fig. 3.2) according to item 2 of the algorithm presented above. The corresponded auxiliary vector $\vec{Y}_{P S}=\left\{X_{P S, \beta} \mid X_{P S, \beta} \in \mathbf{V}_{\beta}\right\}, \beta=\overline{1, N_{X, P S}}$, of the unknown initial pre-stressing forces with start zero values for all components $X_{P S, \beta}$ were formed, $\vec{Y}_{P S}=\left(X_{P S, 1}, X_{P S, 2}, \ldots X_{P S, 7}\right)^{T}=(0.0,0.0, \ldots, 0.0)^{T}$.

According to item 3 the vector for the gradient of function $\mathbf{S}_{\sigma}$ (2.1) has been calculated for all variable pre-stressing parameters (unknown initial prestressing forces) $\vec{Y}_{P S}$ when variable cross-section parameters $\vec{X}_{C S}$ (unknown cross-sectional sizes) of the cross-beam structure have been fixed at the level of $\vec{X}_{C S}=\vec{X}_{C S, N_{R M}=0}^{*}$ (see Table. 3.1).

An order of the consecutive including of the pre-stressing variants $\mathbf{V}_{m}=\left\{\mathbf{r}_{m}, X_{P S, m}\right\}=\left\{\left\{r_{m, \mu}\right\}, X_{P S, m}\right\}, \mu=\overline{1, N}_{R M, m}$, from set $\mathbf{B}$ of the pre-defined pre-stressing variants into set $\boldsymbol{\Theta}$ represented the optimal pre-stressing variants has been determined based on the values of the criteria (2.3) (see Table 3.1).

According to item 6 of the algorithm presented above the unknown initial pre-stressing force $X_{P S, 2}$ corresponded to the pre-stressing variant $\mathbf{V}_{2}$ has been added to the design variable vector first of all, $\vec{X} \leftarrow \vec{X}+X_{P S, 2}$, $\vec{X}=\left(h_{w}, t_{w}, b_{f}, t_{f}, X_{P S, 2}\right)^{T}$.

The optimum material and internal forces problem (3.1), (1.9), (1.10), (1.11), (1.15), (1.18), (1.19), (1.21), (1.6) has been formulated and solved in the continuum space of the unknown cross-sectional sizes and unknown initial pre-stressing forces. Optimum continuous cross-sectional sizes $[\mathrm{cm}]$ for all beams of the cross-beam structure and initial pre-stressing force $[\mathrm{t}]$ :

$$
\vec{X}_{N_{R M}=2}^{*}=(202.5226,1.9750,77.9167,2.5920,-59.1910)^{T},
$$

corresponded to the material weight $G_{N_{R M}=2}^{*}=90.2934$ ton of the structure has been obtained for the case when the number of redundant members to introduce initial pre-stressing forces $X_{P S, 2}=-59.1910$ ton is $N_{R M}=2$. There 
were 102 active constraints in the optimum point including strength constraints (1.9) formulated for $6^{\text {th }}, 7^{\text {th }}, 17^{\text {th }}, 18^{\text {th }}, 19^{\text {th }}$ and $20^{\text {th }}$ structural members (see Fig. 3.1), as well as local buckling constraints (1.18), (1.19) formulated for all design sections of all structural members. The set of linear-independent constrains included 5 constraints (that is equal to the number of the design variables), namely 3 strength constraints (1.9) for $19^{\text {th }}, 20^{\text {th }}$ and $7^{\text {th }}$ structural members (see Fig. 3.1), as well as web local buckling constraint $(1.18)$ for $2^{\text {nd }}$ structural member and flange local buckling constraint (1.19) for $1^{\text {st }}$ structural member. Introducing the initial pre-stressing force into the redundant members of the cross-beam structure according to the second pre-stressing variant (see Fig. 3.2 (b)) has been ensured the material economy y po3мipi $4.73 \%$ comparing to the weight of the cross-beam structure without pre-stressing.

Table 3.1

Determination of the order of the consecutive including of the pre-defined prestressing variants into the set of optimal pre-stressing variants

\begin{tabular}{|c|c|c|c|c|c|}
\hline $\begin{array}{c}\text { Pre- } \\
\text { stressing } \\
\text { variant, } \beta\end{array}$ & $\begin{array}{c}\text { Number of } \\
\text { redundant } \\
\text { members } \\
\mathbf{r}_{\beta}, N_{R M, \beta}\end{array}$ & $\begin{array}{c}\text { Initial pre- } \\
\text { stressing } \\
\text { force } X_{P S, \beta}\end{array}$ & $\begin{array}{c}\text { Components } \\
\frac{\partial \mathbf{S}_{\sigma}}{\partial X_{P S, \beta}} \times 10^{-6}\end{array}$ & $\begin{array}{c}\text { Criteria } \\
(2.3)\end{array}$ & Order \\
\hline 1 & 2 & $X_{P S, 1}$ & 8.1133 & 4.0566 & 2 \\
\hline 2 & 2 & $X_{P S, 2}$ & 8.1170 & 4.0585 & 1 \\
\hline 3 & 4 & $X_{P S, 3}$ & -7.7961 & 1.9490 & 3 \\
\hline 4 & 4 & $X_{P S, 4}$ & -7.7877 & 1.9469 & 4 \\
\hline 5 & 4 & $X_{P S, 5}$ & $3.0895 \cdot 10^{-4}$ & $0.7723 \cdot 10^{-4}$ & 6 \\
\hline 6 & 4 & $X_{P S, 6}$ & $2.6861 \cdot 10^{-4}$ & $0.6715 \cdot 10^{-4}$ & 7 \\
\hline 7 & 2 & $X_{P S, 7}$ & $3.0895 \cdot 10^{-4}$ & $1.5448 \cdot 10^{-4}$ & 5 \\
\hline
\end{tabular}

On the second iteration of the searching process for optimal pre-stressing variant of the cross-beam structure the unknown initial pre-stressing force $X_{P S, 1}$ corresponded to the pre-stressing variant $\mathbf{V}_{1}$ has been added to the design variable vector $\vec{X} \leftarrow \vec{X}+X_{P S, 1}, \quad \vec{X}=\left(h_{w}, t_{w}, b_{f}, t_{f}, X_{P S, 2}, X_{P S, 1}\right)^{T}$. The optimum material and internal forces problem (3.1), (1.9), (1.10), (1.11), (1.15), (1.18), (1.19), (1.21), (1.6) has been formulated and solved in the continuum space of the unknown cross-sectional sizes and unknown initial pre-stressing forces. Optimum continuous cross-sectional sizes [cm] for all beams of the cross-beam structure and initial pre-stressing forces $[\mathrm{t}]$ :

$$
\vec{X}_{N_{R M}=4}^{*}=(195.9161,1.9105,75.3726,2.5074,-66.6490,-67.4819)^{T},
$$

corresponded to the material weight $G_{N_{R M}=4}^{*}=84.4959$ ton of the structure has 
been obtained for the case when the number of redundant members to introduce initial pre-stressing forces $X_{P S, 2}=-66.6490$ ton and $X_{P S, 1}=-67.4819$ ton is $N_{R M}=4$. There were 106 active constraints in the optimum point including strength constraints (1.9) formulated for $2^{\text {nd }}, 3^{\text {rd }}, 6^{\text {th }}$, $7^{\text {th }}, 10^{\text {th }}, 11^{\text {th }}, 14^{\text {th }}, 15^{\text {th }}, 22^{\text {th }}$ and $23^{\text {th }}$ structural members (see Fig. 3.1), as well as local buckling constraints (1.18), (1.19) formulated for all design sections of all structural members. The set of linear-independent constrains included 5 constraints (that is less than the number of the design variables), namely 3 strength constraints $(1.19)$ for $6^{\text {th }}, 22^{\text {th }}$ and $10^{\text {th }}$ structural members (see Fig. 3.1 ), as well as web and flange local buckling constraint (1.18), (1.19) for the $1^{\text {st }}$ structural member. Introducing the initial pre-stressing force into the redundant members of the cross-beam structure according to the second (see Fig. 3.2 (b)) and first pre-stressing variants (see Fig. 3.2 (a)) has been ensured the material economy $11.9 \%$ comparing to the weight of the cross-beam structure without pre-stressing and material economy $6.86 \%$ comparing to the weight of the cross-beam structure with second pre-stressing variant only.

On the third iteration of the searching process for optimal pre-stressing variant of the cross-beam structure the unknown initial pre-stressing forces $X_{P S, 3}$ and $X_{P S, 4}$ corresponded to the pre-stressing variant $\mathbf{V}_{3}$ (see Fig. 3.2 (c)) and $\mathbf{V}_{4}$ (see Fig. 3.2 (d)) respectively have been added to the design variable vector $\vec{X} \leftarrow \vec{X}+X_{P S, 3}+X_{P S, 4}, \vec{X}=\left(h_{w}, t_{w}, b_{f}, t_{f}, X_{P S, 2}, X_{P S, 1}, X_{P S, 3}, X_{P S, 4}\right)^{T}$. The optimum material and internal forces problem (3.1), (1.9), (1.10), (1.11), (1.15), (1.18), (1.19), (1.21), (1.6) has been formulated and solved in the continuum space of the unknown cross-sectional sizes and unknown initial pre-stressing forces. Optimum continuous cross-sectional sizes $[\mathrm{cm}]$ for all beams of the cross-beam structure and initial pre-stressing forces [t]:

$$
\begin{gathered}
\vec{X}_{N_{R M}=4}^{*}=(195.7524,1.9089,75.3101,2.5053, \\
-46.3229,-47.2695,19.4231,20.9016)^{T},
\end{gathered}
$$

corresponded to the material weight $G_{N_{R M}=4}^{*}=84.3553$ ton of the structure has been obtained for the case when the number of redundant members to introduce initial pre-stressing forces $X_{P S, 2}=-46.3229$ ton, $X_{P S, 1}=-47.2695$ ton,$\quad X_{P S, 3}=19.4231$ ton $\quad$ and $\quad X_{P S, 4}=20.9016$ ton is $N_{R M}=12$. There were 108 active constraints in the optimum point including strength constraints (1.9) formulated for $2^{\text {nd }}, 3^{\text {rd }}, 6^{\text {th }}, 7^{\text {th }}, 10^{\text {th }}, 11^{\text {th }}, 14^{\text {th }}, 15^{\text {th }}$, $18^{\text {th }}, 19^{\text {th }}, 22^{\text {th }}$ and $23^{\text {th }}$ structural members (see Fig. 3.1), as well as local buckling constraints (1.18), (1.19) formulated for all design sections of all structural members. The set of linear-independent constrains included 6 constraints (that is less than the number of the design variables), namely 4 strength constraints (1.9) for $7^{\text {th }}, 19^{\text {th }}, 11^{\text {th }}$ and $15^{\text {th }}$ structural members (see Fig. 3.1 , as well as web and flange local buckling constraint (1.18), (1.19) for the 
$1^{\text {st }}$ structural member. Introducing the initial pre-stressing force into the redundant members of the cross-beam structure according to the second (see Fig. 3.2 (b)), first (see Fig. 3.2 (a)), third (see Fig. 3.2 (c)) and forth (see Fig. 3.2 (d)) pre-stressing variants has been ensured the material economy $12.10 \%$ comparing to the weight of the cross-beam structure without prestressing and material economy $0.17 \%$ comparing to the weight of the crossbeam structure with previous first and second pre-stressing variants only.

Since, decrement of the objective function value is less than $1 \%$ comparing to one for considered structure with previous pre-stressing variants, so introducing the initial forces into the redundant members according to $3^{\text {rd }}$ and $4^{\text {th }}$ pre-stressing variants (see Fig. 3.2 (c), (d)) is not effective. Searching for optimal pre-stressing variant of the considered cross-beam structure can be finished. Thus, the optimal pre-stressing variant of the considered cross-beam structure consists of the $1^{\text {st }}$ and $2^{\text {nd }}$ pre-stressing variants (see Fig. 3.2 (a), (b)) and can be created by lowering external $2^{\text {nd }}, 5^{\text {th }}, 8^{\text {th }}$ and $11^{\text {th }}$ supports. The optimal number of the redundant members for introducing the initial prestressing forces is 4 respectively.

In order to define the optimal pre-stressing variant for considered cross beam structure three optimum material and internal forces distribution problems only have been solved with the number of variable initial prestressing forces 1, 2 and 3 respectively.

As it has been shown by presented numerical example, proposed numerical technique to determine the optimal number of the redundant members to introduce initial pre-stressing forces ensures decreasing of the number of optimum material and internal forces distribution problems that should be solved, as well as reduction of the dimension for the design variable vector of unknown initial pre-stressing forces for considered optimization problems.

Conslusion. A numerical technique to determine the optimal number of the redundant members to introduce initial prestressing forces has been offered for high-order statically indeterminate bar structures. An idea to form an optimal prestressing variant for the considered bar structure by consecutive introduction of the initial prestressing forces into the redundant members and subsequent solving of the optimum material and internal forces distribution problems has been suggested. An order of the consecutive including of the initial prestressing forces into the redundant members can be defined by values of the components of the gradient vector for the function that estimates both under-stressing and overstressing in term of longitudinal stresses for all structural members of the bar system with respect to the variable prestressing parameters.

The suggested numerical technique to determine the optimal number of the redundant members to introduce initial prestressing forces provides the reduction of the dimension for the design variable vector of unknown initial prestressing forces for considered optimization problems. 


\section{REFERENCES}

1. Markandeya P. R. Computerized optimum dimensioning of prestressed homogenous steel Ibeam / P. R. Markandeya, R. Vipparthy // Engineering Journal. - 2017. - №21(7). - P. 293381. DOI:10.4186/ej.2017.21.7.293

2. Magnel G. Prestressed steel structures / G. Magnel // The Structural Engineer. - 1950. №28. - P. 285-295.

3. Gasperi B. B. A. Behaviour of prestressed steel beams / B. B. A. Gasperi // Journal of Structural Engineering ASCE. - 2010. - №136(9). - P. 1131 - 1139.

4. Ghafooripour A. Flooring systems with prestressed steel stringers for cost benefit / A. Ghafooripour, A. Nidhi, R. Barreto, A. Rivera // Journal of Steel Structures and Construction. - 2019. - №5(1). - Article 1000150.

5. Saito D. Optimal prestressing and configuration of stayed columns / D. Saito, M. A. Wadee // Proceedings of the Institution of Civil Engineers-Structures and Buildings. - 2010. - №163. - P. 343-355.

6. Wadee M. A. Design of prestressed stayed columns / M. A. Wadee, L. Gardner, A. I. Osofero // Journal of Constructional Steel Research. - 2013. - №80. P. 82-90.

7. Han K. B. Parametric study of truss bridges by the post-tensioning method / K. B. Han, S. K. Park // Canadian Journal of Civil Engineering. - 2005. - №32. - P. 420-429.

8. Aydin Z. Cost minimization of prestressed steel trusses considering shape and size variables / Z. Aydın, E. Cakir // Steel and Composite Structures. - 20415. - №19(1). P. 43-58.

9. Schmidt L. C. Studies on post-tensioned and shaped space-truss domes / L. C. Schmidt, H. Li // Structural Engineering and Mechanics. - 1998. - №6. - P. 693-710.

10. Clarke M. J. Simple design procedure for cold-formed tubular top chord of stressed-arch frames / M. J. Clarke, G. J. Hancock // Engineering Structures. - 1994. - №16(5). P. 377385.

11. Kyoungsoo L. Analysis of stabilizing process for stress-erection of starch frame / L. Kyoungsoo, H. Ziaul, H. SangEul // Engineering Structures. - 2014. №59. P. 49-67.

12. Haug E.J. Applied optimal design: mechanical and structural systems / E. J. Haug, J. S. Arora. - John Wiley \& Sons, 1979.

13. Olkov Ya. I. Optimal noe proektirovanie metallicheskikh predvaritel'no napryazhenny'kh ferm [Optimal design of pre-stressed metal trusses (in Russian)] / Ya. I. Olkov, I. S. Kholopov. - Moscow, Stroyizdat, 1985.

14. Gkantou M. Optimisation of high strength steel prestressed trusses / M. Gkantou, M. Theofanous, C. Baniotopoulos // Proceedings of $8^{\text {th }}$ GRACM International Congress on Computational Mechanics. - 2015. - P. 10.

15. Yao L. Topology optimization design of pre-stressed plane entity steel structure with the constrains of stress and displacement / L. Yao, Y. X. Gao, H. J. Yang // Advanced Materials Research. - 2014. - №945-949. - P. 1216-1222.

16. Zhou $Z$. A whole process optimal design method for prestressed steel structures considering the influence of different pretension schemes / Z. Zhou, S. Meng, J. Wu // Advances in Structural Engineering. - 2012. - №15(12). - P. 2205-2212.

17. Serpik I. N. Searching for efficient parameters of pre-stressed long-span steel trusses with several ties / I. N. Serpik, N. V. Tarasova // Proceeding of the International theoretical and practical conference "Bryansk Innovations in Construction". - 2017. - P. 285-290.

18. Serpik I. N. Parametric optimization of pre-stressed steel arch-shaped trusses with ties / I. N. Serpik, N. V. Tarasova // IOP Conference Series: Materials Science and Engineering. 2018. - №451. - Article 012060. DOI:10.1088/1757-899X/451/1/012060

19. Huebner K. H. The finite element method for engineers $\left(4^{\text {th }}\right.$ ed.) $/$ K. H. Huebner, D. L. Dewhirst, D. E. Smith, T. G. Byrom. - John Wiley \& Sons, Inc. 2001. - 744 p.

20. DBN V.2.6-198:2014. Stalevi konstruktsii. Normy proektuvannia [Steel structures. Design codes (in Ukrainian)] - Kyiv: Minregion of Ukraine, 2014. - 199 p.

21. Guljaev V.I. Metody' optimizaczii v stroitel'noj mekhanike [Optimisation methods in structural mechanic (in Russian)] / V. I. Guljaev, V. A. Bazhenov, V. L. Koshkin. - Kyiv, 1988. - $192 \mathrm{p}$.

22. Yurchenko V. Parametric optimization of steel truss with hollow structural members based on update gradient method / V. Yurchenko, I. Peleshko, N. Beliaev // Proceedings of 
International Conference "Design, Fabrication and Economy of Metal Structures". - Springer Berlin Heidelberg, 2013. - P. 103-109. DOI 10.1007/978-3-642-36691-8_16

23. Peleshko I. Parametric optimization of steel structures based on gradient projection method/ I. Peleshko, V. Yurchenko // Strength of Materials and Theory of Structures: Scientific-andtechnical collected articles. - Kyiv: KNUBA, 2020. - Issue 105. - P. 192-220. DOI: $10.32347 / 2410-2547.2020 .105 .192-220$.

24. Yurchenko $V$. Improved gradient projection method for parametric optimisation of bar structures / V. Yurchenko, I. Peleshko // Magazine of Civil Engineering. - 2020. - №98(6). Article 9812. DOI: 10.18720/MCE.98.12.

25. Peleshko I. An improved gradient-based method to solve parametric optimisation problems of the bar structures / I. Peleshko, V. Yurchenko // Strength of Materials and Theory of Structures: Scientific-and-technical collected articles. - Kyiv: KNUBA, 2020. - Issue 104. P. 265-288. DOI: 10.32347/2410-2547.2020.104.265-288.

26. Kuci E. Design sensitivity analysis for shape optimization based on the Lie derivative / E. Kuci, F. Henrotte, P. Duysinx, C. Geuzaine // Computer methods in applied mechanics and engineering. - 2017. - Vol. 317. - P. 702-722. DOI: 10.1016/j.cma.2016.12.036.

27. YURCHENKO V.V. SEARCHING FOR OPTIMAL PRE-STRESSING OF STEEL BAR STRUCTURES BASED ON SENSITIVITY ANALYSIS / V. YURCHENKO, I. PELESHKO // ARCHIVES OF CIVIL ENGINEERING, VOL. 66, NO. 3, 2020. - P. 525540. DOI: $10.24425 /$ ACE.2020.134411.

Стаття надійшла 25.03.2021

Юрченко В. В., Пелешко І. Д.

ОПТИМАЛЬНА КІЛЬКІСТЬ ЗАЙВИХ В'ЯЗЕЙ ДЛЯ ВВЕДЕННЯ ЗУСИЛЬ ПОПЕРЕДНЬОГО НАПРУЖЕННЯ МЕТАЛЕВИХ СТЕРЖНЕВИХ СИСТЕМ

У статті розглядається задача параметричної оптимізації металевих стержневих систем, представлена як задача нелінійного програмування зі змінними (невідомими) розмірами поперечних перерізів елементів конструкції, а також зусиллями попереднього напруження, що вводяться у визначені зайві в'язі стержневої системи. Система обмежень охоплює обмеження несучої здатності, що формулюються для усіх розрахункових перерізів несучих елементів конструкції, що підлягає дії усіх розрахункових комбінацій навантажень першої групи граничних станів, а також обмеження переміщень визначених вузлів стержневої системи, що підлягає дії усіх розрахункових комбінацій навантажень другої групи граничних станів. Для розв'язку задачі параметричної оптимізації використовувався метод проекції градієнта функції мети на поверхню активних обмежень з одночасною ліквідацією нев'язок в порушених обмеженнях. Для складних багато раз статично невизначених стержневих систем запропонована чисельна методика визначення оптимальної кількості зайвих в'язей для введення зусиль попереднього напруження.

Ключові слова: параметрична оптимізація, зайва в'язь, зусилля попереднього напруження, оптимальне попереднє напруження, аналіз чутливості, метод проекції градієнта.

\section{Yurchenko V. V., Peleshko I. D.}

\section{OPTIMAL NUMBERS OF THE REDUNDANT MEMBERS FOR INTRODUCING INITIAL PRE-STRESSING FORCES INTO STEEL BAR STRUCTURES}

The paper considers parametric optimization problems for the steel bar structures formulated as nonlinear programming ones with variable unknown cross-sectional sizes of the structural members, as well as initial prestressing forces introduced into the specified redundant members of the structure. The system of constraints covers load-bearing capacity constraints for all the design sections of the structural members subjected to all the design load combinations at ultimate limit state, as well as displacement constraints for the specified nodes of the bar system, subjected to all design load combinations at serviceability limit state. The method of the objective function gradient projection onto the active constraints surface with simultaneous correction of the constraints violations has been used to solve the parametric optimization problem. A numerical 
technique to determine the optimal number of the redundant members to introduce the initial prestressing forces has been offered for high-order statically indeterminate bar structures.

Keywords: parametric optimization, redundant member, initial prestressing force, optimal prestressing, sensitivity analysis, gradient projection method.

\section{Юрченко В. В., Пелешко И. Д.}

\section{ОПТИМАЛЬНОЕ КОЛИЧЕСТВО ЛИШНИХ СВЯЗЕЙ ДЛЯ ВВЕДЕНИЯ УСИЛИЙ ПРЕДВАРИТЕЛЬНОГО НАПРЯЖЕНИЯ МЕТАЛЛИЧЕСКИХ СТЕРЖНЕВЫХ СИСТЕМ}

В статье рассмотрена задача параметрической оптимизации металлических стержневих систем, представленная как задача нелинейного программирования с переменными (неизвестными) размерами поперечных сечений элементов конструкции, а также усилий предварительного напряжения, которые вводяться в определенные лишние связи стержневой системы. Система ограничений охватывает ограничения несущей способности, сформулированные для всех расчетных сечений несущих элементов конструкции, подлежащей действию всех расчетных комбинаций нагрузок первой группы предельных состояний, а также ограничения перемещений определенных узлов стержневой системы, подлежащей действию всех расчетных комбинаций нагрузок второй группы предельных состояний. Для решения задачи параметрической оптимизации использовался метод проекции градиента функции цели на поверхность активных ограничений при одновременной ликвидации нев'язок в нарушенных ограничениях. Для сложных много раз статически неопределенных стержневых систем предложена численная методика определения оптимального количества лишних свіязей для введения усилий предварительного напряжения.

Ключевые слова: параметрическая оптимизация,лишняя связь, усилие предварительного напряжения, оптимальное предварительное напряжение, анализ чувствительности, метод проекции градиента.

\section{УДК $624.04,519.853$}

Юрченко В. В., Пелешко І. Д. Оптимальна кількість зайвих в'язей для введення зусиль попереднього напруження металевих стержневих систем // Опір матеріалів і теорія споруд: наук.-тех. збірн. - К.: КНУБА, 2021. - Вип. 106. - С. 68-91.

У статті розглядається задача параметричної оптимізації металевих стержневих систем, представлена як задача нелінійного програмування зі змінними (невідомими) розмірами поперечних перерізів елементів конструкиії, а також зусиллями попереднього напруження, що вводяться у визначені зайві в'язі стержневої системи. Система обмежень охоплює обмеження несучої здатності, щзо формулюються для усіх розрахункових перерізів несучих елементів конструкції, що підлягає дії усіх розрахункових комбінацій навантажень першої групи граничних станів, а також обмеження переміщень визначених вузлів стержневої системи, що підлягає дії усіх розрахункових комбінацій навантажень другої групи граничних станів. Для розв'язку задачі параметричної оптимізачї̈ використовувався метод проекції градієнта функиії мети на поверхню активних обмежень з одночасною ліквідачією нев'язок в порушених обмеженнях. Для складних багато раз статично невизначених стержневих систем запропонована чисельна методика визначення оптимальної кількості зайвих в'язей для введення зусиль попереднього напруження.

Іл. 3. Табл. 1. Бібліог. 27 назв.

\section{УДК $624.04,519.853$}

Yurchenko V. V., Peleshko I. D. Optimal numbers of the redundant members for introducing initial pre-stressing forces into steel bar structures // Strength of Materials and Theory of Structures: Scientific-and-technical collected articles - Kyiv: KNUBA, 2021. - Issue 106. - P. 6891.

The paper considers parametric optimization problems for the steel bar structures formulated as nonlinear programming ones with variable unknown cross-sectional sizes of the structural members, as well as initial prestressing forces introduced into the specified redundant members of the structure. The system of constraints covers load-bearing capacity constraints for all the design 
sections of the structural members subjected to all the design load combinations at ultimate limit state, as well as displacement constraints for the specified nodes of the bar system, subjected to all design load combinations at serviceability limit state. The method of the objective function gradient projection onto the active constraints surface with simultaneous correction of the constraints violations has been used to solve the parametric optimization problem. A numerical technique to determine the optimal number of the redundant members to introduce the initial prestressing forces has been offered for high-order statically indeterminate bar structures.

Figs. 3. Tabs. 1. Refs. 27.

УДК $624.04,519.853$

Юрченко В. В., Пелешко И. Д. Оптимальное количество лишних связей для введения усилий предварительного напряжения металлических стержневых систем // Сопротивление материалов и теория сооружений: науч.- тех. сборн. - К.: КНУСА, 2021. Вып. 106. - С. 68-91.

В статье рассмотрена задача параметрической оптимизации металлических стержневих систем, представленная как задача нелинейного программирования $c$ переменными (неизвестными) размерами поперечных сечений элементов конструкиии, а также усилий предварительного напряжения, которые вводяться в определенные лишние связи стержневой системы. Система ограничений охватывает ограничения несущей способности, сформулированные для всех расчетных сечений несущиих элементов конструкиии, подлежащей действию всех расчетных комбинаций нагрузок первой группы предельных состояний, а также ограничения перемещений определенных узлов стержневой системы, подлежащей действию всех расчетных комбиначий нагрузок второй группы предельных состояний. Для решения задачи параметрической оптимизации использовался метод проекиии градиента функиии иели на поверхность активных ограничений при одновременной ликвидации нев'язок в нарушенных ограничениях. Для сложных много раз статически неопределенных стержневых систем предложена численная методика определения оптимального количества лишних свіязей для введения усилий предварительного напряжения.

Ил. 3. Табл. 1. Библиог. 27 назв.

Автор: доктор технічних наук, професор кафедри металевих та дерев'яних конструкцій Юрченко Віталіна Віталї̈вна

Адреса робоча: 03680 Украӥна, м. Київ, Повітрофлотський пр. 31, Київський національний університет будівництва і архітектури

Робочий тел.: +38(044)249-71-91

Мобільний тел..: +38(063)89-26-491

E-mail: vitalina@scadsoft.com

SCOPUS ID: 25637856200

ORCID ID: https://orcid.org/0000-0003-4513-809X

Автор: кандидат технічних наук, доцент кафедри будівельного виробнищтва

Пелешко Іван Дмитрович

Адреса робоча: 79013 Украӥна, м. Львів, вул.. Ст. Бандери 12, Національний університет «Львівська політехніка»

Робочий тел.: +38 (032) 258-25-41

Мобільний тел..: +38(098)41-57-517

E-mail: ipeleshko@polynet.lviv.ua

SCOPUS ID: 25637832500

ORCID ID: https://orcid.org/0000-0001-7028-9653 